ACTA UNIVERSITATIS LODZIENSIS

FOLIA LITTERARIA POLONICA 2(32) 2016

http://dx.doi.org/10.18778/1505-9057.32.03

Lilia R. Duskajewa*

\title{
Dziennikarski styl zawodowy. Próba zdefiniowania
}

\section{Wstęp}

Każdy narodowy język literacki wykorzystuje się w rozmaitych dziedzinach komunikacji działalności społecznej, w których cele i warunki komunikacji są niejednakowe. $Z$ tego względu w słowiańskiej stylistyce funkcjonalnej uzasadniony jest podział języków literackich na sześć stylów funkcjonalnych, kształtujących się w społecznie znaczących obszarach komunikowania1. Podział zaś na podstyle i gatunki mowy ${ }^{2}$ jest powszechnie przyjęty $\mathrm{w}$ związku z różnorodnością problemów, jakie analizowane są w kontekście stylów funkcjonalnych.

Rozpowszechnione w stylistyce funkcjonalnej podejście do stylów mowy jako do reprezentantów różnych obszarów działalności ${ }^{3}$ otwiera możliwość wyróżnienia w ramach stylów funkcjonalnych innego rodzaju - stylów zawodowych. W lingwistyce określenie „zawodowy” jako termin często używa się razem z rzeczownikiem „język", ale z reguły mówi się w tej sytuacji o jednej z klas leksyki: językiem zawodowym nazywa się całokształt wyrazów specyficznych dla użycia w wypowiedzi

* PhD, prof., e-mail: 1rd2005@yandex.ru; Санкт-Петербургский Государственный Университет, Институт „Высшая Школа Журналистики и Массовых Коммуникаций”, Кафедра речевой коммуникации; 1-я линия В.О., Д. 26, 199004, Санкт-Петербург.

${ }^{1}$ Zob. prace rosyjskich uczonych: M.N. Kożyna, L.R. Duskajewa, W.A. Salimowski, Stilistika russkogo jazyka, Izdatiel'stwo Flinta, Moskwa 2008, s. 84; polskich: Przewodnik po stylistyce polskiej, red. nauk. S. Gajda, Uniwersytet Opolski, Opole 1995; czeskich: M. Chehova, J. Chloupek, M. Krčmova, E. Minařova, Současna česka stylistika, ISV, Praha 2003; słowackich: J. Mistrik, Štylistika, Wydawnictwo SPN, Bratislava 1997.

${ }^{2}$ W.A. Salimowski, Żanry reczi v funcjonalno-stilisticzeskom oswieszczenii (nauczny akademickij tekst), Izdatiel'stwo Permskogo uniwiersiteta, Perm 2002.

${ }^{3} \mathrm{~K}$. Gauzenblas, K utoczneniju ponjatija , stil” $i$ k voprosu ob objome stilisticzeskogo issledowanija, „Woprosy Jezykoznania” [,Problemy Językoznawstwa”] 1965, nr 5; tenże, Suszczestwujet li „,neutralnyj stil”?, [w:] Funkcjonalnaja stilistika. Teorija stilej i ich jazykowaja realizacija, Izdatiel'stwo Permskogo uniwiersiteta, Perm 1986; S. Gajda, Stilistika i genealogija. Status stilistiki w sowremennom jazykoznanii, Izdatiel'stwo Permskogo uniwiersiteta, Perm 1992; tenże, Probliemy żanra, [w:] Funkcjonalnaja stilistika...; M.N. Kożyna, Stilistika russkogo jazyka, Izdatiel'stwo Proswiesienie, Moskwa 1977. 
w ramach grupy użytkowników reprezentujących jeden zawód. Jednak sądzimy, że orientacja zawodowa przy użyciu języka w tej czy innej dziedzinie zawodowej odzwierciedla się nie tylko w leksyce ${ }^{4}$. Cele i problemy komunikowania zawodowego mają wpływ na dobór i kombinację środków wszystkich poziomów systemu językowego i kształtują systemowość mowy, składającą się na wyrażenie ważnych znaczeń z zawodowego punktu widzenia ${ }^{5}$. Innymi słowy, można mówić o badaniu struktury słownej tekstów ze specyficznymi cechami, o specyficznym stylu - o stylu zawodowym. Margarita N. Kożyna pisała: „Nie jedna, a kilka różnych definicji stylu jest zjawiskiem uzasadnionym; jedynie trzeba rozróżniać, o jaki [wyróżniony] aspekt badań chodzi"`. Spróbujmy ogólnie scharakteryzować podobne podejście.

Pojęcie stylu zawodowego jest przydatne, by opisać prawidłowości twórczej działalności werbalnej realizowanej w sferze zawodowej podczas kształcenia zawodowej działalności werbalnej. Styl zawodowy, jak i styl funkcjonalny jest powiązany z działalnością człowieka, odzwierciedla sens i charakter samej działalności jako procesu lub jej cech w produktach - tekstach; stanowi system różnopoziomowych środków językowych, które wybiera się i łączy ze względu na cel komunikacyjny. Ta tworząca się w tekstach systemowość cechuje specyficzność twórczej działalności człowieka lub jej produktów w takiej czy innej sferze komunikacji?

W stylistyce rosyjskiej tradycyjnie jest wyróżniany funkcjonalny styl publicystyczny, który odzwierciedla działalność informacyjną i perswazyjną̧, i przejawia się w różnych formach. Naukowcy wyróżnili w nim szereg charakterystycznych cech stylistycznych. W wyniku dwukierunkowości stylu funkcjonalnego - informowania i oddziaływania perswazyjnego - styl ten cechuje się połączeniem standardu i ekspresji, przy czym standard jest umotywowany charakterem informacyjnym, a ekspresja - perswazjąa . Najczęściej ekspresyjność przejawia się bardziej aktywnie, dlatego ekspresja jest wyrażona silniej i jest widoczna $\mathrm{w}$ otwartym społecznym ocenianiu ${ }^{10}$, motywowaniu ${ }^{11}$, nastawieniu na oryginalność wyrażenia ${ }^{12}$. Jednak w toku rozwoju tego stylu w epoce postra-

${ }^{4}$ Zob. badania Stanisława Grabiasa na ten temat w: tenże, Język w zachowaniach społecznych, wyd. 2 popr., Wydawnictwo UMCS, Lublin 1997.

${ }^{5}$ Używam pojęcia systemowości w ujęciu stylistycznym, wypracowanym w rosyjskiej tradycji naukowej. Zob. M.N. Kożyna, Systemowost' reczi, [w:] Stilisticzeskij enciklopediczeskij słovar', ried. M.N. Kożyna, Izdatiel'stwo Flinta, Moskwa 2003, s. 347-350.

${ }^{6}$ M.N. Kożyna, L.R. Duskajewa, W.A. Salimowski, dz. cyt., s. 84.

7 Tamże, s. 85.

${ }^{8}$ W.G. Kostomarow, Russkij jazyk w żurnalie, Izdatiel'stwo Moskowskogo uniwiersiteta, Moskwa 1971. M.N. Kożyna, dz. cyt.; A.N. Wasiljewa, Gezetnogo-publiczistyczeskij stil, Izdatiel'stwo Russkij jazyk, Moskwa 1982.

${ }^{9}$ W.G. Kostomarow, dz. cyt.

${ }^{10}$ G.J. Solganik, Stil' reportaża, Izdatiel'stwo Moskowskogo uniwiersiteta, Moskwa 1970.

11 A.N. Wasiljewa, dz. cyt.

12 M.N. Kożyna, dz. cyt. 
dzieckiej różnicował się on na podstyle zawodowe - dziennikarski, reklamowy, polityczny i PR, bo wszystkie wyróżnione w stylu publicystycznym cechy są wyrażone w wymienionych zawodowych odmianach stylistycznych, w różny sposób przynależnych do makrostylu publicystycznego.

Połączenie standardu i ekspresji może być rozmaite, gdyż ekspresywność jest wyrażana bardzo specyficznie. W tekstach PR-owych ma ono strukturę przeważnie standardową, a w tekstach reklamowych jest dużo ekspresji, ale sama korelacja jest konieczna. Jawne ocenianie w dziennikarstwie widoczne jest w sposobie wyrażenia stosunku do przedmiotu wypowiedzi z punktu widzenia interesu takiej czy innej wspólnoty społecznej, dlatego definiuje się je jako społeczne ${ }^{13}$. W stylu reklamowym ocenianie jest utylitarne ${ }^{14}$, w stylu PR-owym - korporacyjne, ponieważ dokonuje się go w interesie korporacji.

W tekście dziennikarskim ocenianie i zachęta mają własną specyfikę: ich celem jest np. uzasadnienie celowości decyzji administracyjnej, wypracowanej przez specjalistów albo samego autora, i często towarzyszy jej wnikliwa, głęboka argumentacja. W stylu dziennikarskim motywacja jest wyrażona bardzo różnorodnie. Niekiedy autor uprzedza społeczeństwo o braku działań w jakiejś sprawie, czasem czytelnik ma do wyboru kilka modeli rozwiązań problemu społecznego, które trzeba porównać ze sobą i wybrać najlepszy ${ }^{15}$. Zachęta jest zatem tylko częścią orientacji aksjologicznej, z pomocą której akceptuje się wartość jakiegoś działania społecznego lub jego pewnego modelu.

Poszukiwanie nowego sposobu wyrażenia różnie przejawia się także w stylach zawodowych. Szczególnie widać je w działalności reklamowej, w której kreatywność jest podstawową cechą. W dziennikarstwie ma ono sens komunikacyjny - to jest właściwość niezbędna dla takiego ujęcia stylistycznego, które byłoby skuteczne perswazyjnie. W działalności PR-owej kreatywność stylistyczna jest prezentowana cząstkowo, tylko w odrębnych gatunkach.

Specyfika realizacji wszystkich stylów zawodowych w obrębie funkcjonalnego stylu publicystycznego określa różnicę między czynnikami pozajęzykowymi. Na przykład faktograficzność stylu dziennikarskiego jest ukierunkowana na odzwierciedlenie rzeczywistości społecznej w całej jej rozmaitości. Styl reklamowy eksponuje unikalne właściwości obiektów przeznaczonych na sprzedaż. W tekstach PR-owych świat odzwierciedla się częściowo: wyjaśnia się tylko to, co ma jakiś związek z działalnością korporacji.

${ }^{13}$ G.J. Solganik, dz. cyt.

${ }^{14}$ J.S. Kara-Murza, Kul'tura reczi w reklamnoj dejatel'nosti, „Żurnalistika i Kul'tura Reczi” 1996, wyp. 1.

${ }^{15}$ Więcej zob. L.R. Duskajewa, Dialogiczeskaja priroda gazetnych reczewych żanrow, Izdatel'stvo Permskogo universiteta, Perm 2004; 2 soz.: Izdatel'stwo Sankt-Peterburgskogo uniwersiteta, Sankt Petersburg 2012. 
Każda odmiana działalności zawodowej realizuje się we właściwych dla niej, typowych działaniach komunikacyjnych.

Za działanie komunikacyjne uważamy akt celowej zawodowej działalności werbalnej, który odbywa się zgodnie z przyjętymi w danej kulturze normami komunikowania. Działanie komunikacyjne realizowane jest przez aktanta mowy w określonej sytuacji werbalnej dla osiągnięcia celu z uwzględnieniem przewidywanej reakcji adresata. Dla organizacji działania komunikacyjnego dobiera się środki językowe $\mathrm{z}$ różnych poziomów, łącząc i zestawiając je zgodnie z zamiarem komunikacyjnym (intencjonalnością). Działanie komunikacyjne, dialogiczne w swojej naturze, jest interakcją, bo już na poziomie kształtowania się intencji formuje się je, biorąc pod uwagę hipotetyczną reakcję adresata.

Strukturę funkcjonalnego stylu publicystycznego prezentuje poniższy schemat ${ }^{16}$.

Schemat 1.

publicystyczny styl funkcjonalny

odzwierciedla

działalność informacyjno-perswazyjną, w tym

działalności zawodowe:
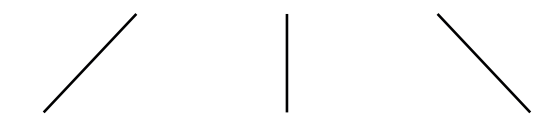

dziennikarską reklamową PR

które realizują się

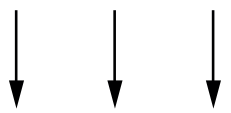

w typowych działaniach komunikacyjnych

Źródło: oprac. własne.

Działania komunikacyjne, współwystępując i przenikając się w różny sposób, współtworzą gatunki mowy, ich tematyczne i ,techniczne” odmiany.

Styl zawodowy zatem to szczególny gatunek mowy, specyficzna organizacja mowy, tworzona w procesie doboru i kombinacji działań komunikacyjnych pod wpływem zwyczajów zawodowych. Podobnie jak style funkcjonalne, są one są rozległymi, skomplikowanymi typami mowy, które tworzą się pod wpływem zespołu podstawowych pozajęzykowych czynników stylotwórczych: rodzaju działalności, rodzaju treści (tematyki) charakterystycznego dla odpowiedniej

\footnotetext{
16 „Styl publicystyczny jest bardzo skomplikowanym zjawiskiem z powodu niejednolitości jego zadań i warunków komunikacji i ogólnie specyficznych cech podstawy pozajęzykowej. Obfituje w rozmaite podstyle i gatunki - ustne i pisemne. W tradycji rosyjskiej styl publicystyczny jest rozważany jako faktograficzna odmiana języka narodowego i obejmuje poza dziennikarską odmianę reklamową i PR-ową" (M.N. Kożyna, L.R. Duskajewa, W.A. Salimowski, dz. cyt.).
} 
zawodowej sfery kontaktów, celów komunikowania zawodowego związanych z oczekiwaniami społecznymi, a także relacji między autorem mowy i adresatem charakterystycznych dla tego czy innego obszaru, itp. Dalej bardziej szczegółowo zajmijmy się analizą dziennikarskiego stylu zawodowego.

\section{Typologia zawodowego stylu dziennikarskiego}

Dla opisu wewnętrznej dyferencjacji stylu zawodowego wprowadźmy pojęcie gatunków mowy, których klasyfikacja wskaże typowe informacyjno-perswazyjne działania komunikacyjne. Obecnie pojęcie „gatunek mowy” szeroko rozpowszechniło się w europejskiej literaturze lingwistycznej i jest stosowane w lingwistyce komunikacyjno-funkcjonalnej przede wszystkim jako naukowe narzędzie typologiczne ${ }^{17}$. Gatunki mowy stanowią wieloplanowe reprodukcyjne formy tekstowej działalności, optymalne wzory efektywnej interakcji werbalnej. W tych wzorcach mowy, jej produktach (tekstach) odzwierciedla się sens i charakter właściwej działalności, ponieważ formują się cechy jej oryginalności w każdej rozpatrywanej dziedzinie i sytuacji komunikowania.

Mimo rozwoju genologii linwistycznej, kwestia definicji gatunku mowy jest otwarta i ujawnia się wyraźnie w przypadku konieczności tworzenia typologii mowy dla tej czy innej dziedziny. Sporne pozostają kwestie podstawowych cech gatunku mowy i podejścia do ich wyodrębniania: jedni badacze uważają go za akt mowy ${ }^{18}$, inni - za bardziej rozwiniętą i skomplikowaną konstrukcję werbalną, składającą się z kilku aktów mowy ${ }^{19}$. Jednak, w ślad za całym szeregiem bada$\mathrm{czy}^{20}$, w niniejszej pracy wykorzystano podejście tekstocentryczne, polegające na tym, że za gatunek uważa się klasę tekstów, a nie działania mowne.

W literaturze naukowej istnieją odmienne podejścia do wyróżniania właściwości gatunków mowy (GM). W opracowaniach pewnych badaczy, jak np. Anny Wierzbickiej i Tatiany W. Szmielowy ${ }^{21}$, w tym celu wykazuje się szereg

${ }^{17}$ B.J. Corbett, Genre and genre analysis, Encyclopedia of Language and Linguistics, ed. E.K. Brown, A. Anderson, Elsevier, Boston 2006, pp. 26-32; W.W. Dementjew, Teorija reczewych żanrow, Izdatiel'stwo Znak, Moskwa 2010; L. Moessnar, Genre, text type, style, register. A terminological maze, "European Journal of English Studies" 2001, No. 5 (2), pp. 131-138; W. Salimowski, dz. cyt.; M. Wojtak, Gatunki prasowe, Wydawnictwo UMCS, Lublin 2004.

${ }^{18}$ A. Wierzbicka, Uniwersal'nyje semanticzeskije primitiwy kak klucz k leksiczeskoj semantike (sfiera emocij), „Reczewyje Żanry” 2005, nr 4, s. 158-182; T.W. Szmielowa, Reczewoj żanr, „Rusistika" $1990, \mathrm{nr} 2$.

${ }^{19}$ N.I. Formanowska, Reczewoje obszczenije. Kommunikatiwno-pragmaticzeskij podhod, Izdatel'stwo Russkij jazyk, Moskwa 2002.

${ }^{20}$ M.in.: S. Gajda, M. Wojtak, B. Bogołębska, W.A. Salimowski.

${ }^{21}$ A. Wierzbicka, dz. cyt., s. 158-182; T.W. Szmielowa, dz. cyt. 
specyficznych parametrów gatunków mowy, które są istotne przy odróżnianiu w planie pragmalingwistycznym jednego GM od drugiego. W tym przypadku gatunek odzwierciedla werbalnie tę czy inną sytuację komunikacyjną. Stanisław Gajda zaproponował uściślanie rozpatrywanego pojęcia przez tworzenie typologii form gatunków, jej podstaw, określając czynniki, które determinują kształtowanie się gatunków mowy ${ }^{22}$. W ślad za Gajdą taką próbę podjęto w stosunku do stylu naukowego ${ }^{23}$. Gatunki mowy są rozpatrywane w przywołanych pracach jako modele, zgodnie z którymi w tekstach obiektywizują się społecznie potrzebne rodzaje działalności humanistycznej. $Z$ takiego traktowania wynika zasada ich systematyzacji według rodzajów działalności zawodowej z przejściem od ogólnych typów działalności socjokulturalnej, współzależnych z formami świadomości (np. regulatywny funkcjonalny styl prawny, współzależny z prawem jako formą świadomości), do bardziej szczegółowych - do stylu zawodowego i jego grup. W tym nurcie badawczym mieści się także podejście intencjonalno-stylistyczne, rozwijające ujęcie stylów funkcjonalnych jako gatunków mowy, wypracowane w naszych badaniach ${ }^{24}$. Forma gatunku jest przez autorkę niniejszego artykułu opisywana jako urzeczywistnienie - z pomocą typowego systemu działań zawodowo-werbalnych - intencji autorskiej, właściwej dla wykonania obowiązków zawodowych.

Bardziej szczegółową dyferencjację gatunków mowy wewnątrz stylu zawodowego proponuję przeprowadzić na podstawie dyferencjacji rodzajów działalności zawodowej, biorąc pod uwagę typowy zestaw intencji każdego z nich. System gatunków dziennikarskich rozpatrujemy jako realizację werbalną procesu orientacji społecznej prowadzonego przez media. Jeśli spojrzymy na dziennikarstwo jak na działalność, która, z jednej strony, odzwierciedla rzeczywistość, a z drugiej - ukierunkowuje wpływ, to celowe jest wyróżnienie następujących intencji typowych dla zawodowej działalności dziennikarza. To jest, po pierwsze, powiadamianie o tym, co się dzieje w świecie, po drugie, ocena tego, co się dzieje, ustalenie tego, co przeszkadza rozwojowi społecznemu, jakie są tego powody i kto jest winny, po trzecie, pobudzenie aktywności społecznej dla promowania społecznych ideałów. Każda rozpatrzona intencja obiektywizuje się w specyficznych dla siebie grupach gatunków mowy, tak więc system gatunków prasowych może być zaprezentowany w trzech wielkich grupach: ukierunkowanych na świat zdarzeń i ludzi - informacyjnych i oceniających - oraz skupiających uwagę audytorium na działaniach w określonym kierunku - motywujących. Grupy te są

${ }^{22}$ S. Gajda, Probliemy...

${ }^{23}$ W. Salimowski, dz. cyt.

${ }^{24}$ L.R. Duskajewa, Dialogiczeskaja priroda...; taż, Intencjonal'nost' reczewoj dejatel'nosti żurnalista. Ontologija i struktura, „Vestnik Sankt-Peterburgskogo Universiteta” 2012, Serija 9: Filologija, Wostokowedenije, Żurnalistika, nr 2, s. 253-260; taż, Stilisticzeskij intent-analiz kak wektor izuczenija reczewych raznowidnostej, „Medialingwistika” 2013, t. 1, s. 81-91. 
wyróżniane na podstawie motywująco-modalnej strony intencjonalności (zawodowo znaczącego nastawienia na cel).

W nastawieniu zawodowo-gatunkowym jest również aspekt przedmiotowy, który może być ustalony, jeśli przedstawi się go w postaci hipotetycznych pytań audytorium (,treściowe oczekiwania adresata”), na które dziennikarz powinien odpowiedzieć zgodnie z zasadami przyjętymi w społeczeństwie informacyjnym. Aby uchwycić spójność sensu typów tekstów, potrzebne było ustalenie referentów typowych dla tekstów dziennikarskich. W semantyce lingwistycznej jako kierunku badającym rozwój od zdań do wypowiedzi są rozpatrywane wydarzenia, procesy, stany, fakty ${ }^{25}$. Kwestię tego, co jest obiektem empirycznym (referentem tekstu dziennikarskiego) w rosyjskiej literaturze teoretycznej dotyczącej dziennikarstwa rozwiązuje się w różny sposób: jedni uznają za takie obiekty rozmaite sytuacje życiowe ${ }^{26}$, inni - wydarzenia i charaktery ${ }^{27}$, jeszcze inni - charaktery i sytuacje ${ }^{28}$. Analiza materiału pokazała zasadność wyróżnienia wydarzeń, charakterów i sytuacji jako referentów. W ten sposób, według semantyki lingwistycznej, grupę informacyjnych gatunków mowy dzieli się na podstawie tego, o czym subiekt zamierza informować: o sytuacji, zdarzeniu, osobie albo cudzej wypowiedzi. W stylu dziennikarskim można wyróżnić więc takie gatunki mowy, jak: „wiadomość o zdarzeniu”, która opiera się na narracji o wydarzeniach; „opis sytuacyjny", który tworzy się głównie przez relacjonowanie sytuacji zaistniałej w takim czy innym miejscu, ,portret informacyjny” w jego odmianach, ,wypowiedź osoby", która przedstawia komunikat o znaczeniu społecznym, nie formułowany przez dziennikarza. Pierwsze trzy gatunki odzwierciedlają coś nowego, co pojawia się w rzeczywistości, a ostatni pokazuje to, co jest czyjąś wiedzą albo opinią.

Do drugiej grupy należą oceniające dziennikarskie gatunki mowy, które powstają dla przedstawienia analizy i są ukierunkowane na odzwierciedlenie opinii (ocen) o rzeczywistości i już istniejących sądów (tekstów). Podczas badań $i$ analiz tego, co zostało utrwalone na pierwszym etapie, dziennikarz ocenia, co może przynieść korzyść i co może wyrządzić szkodę, co może sprzyjać postępowi społecznemu i co jest dla niego szkodliwe, co jest etyczne, a co nie - w ten

${ }^{25}$ Zob. np.: N.D. Aructunowa, Jazyk i mir czełowieka, „Slawianskij Jazyk i Kul'tura” 1999; J.P. Bryzgunowa, Semanticzeskaja sowmestimost' teksta. Sintaksis teksta, Izdatel'stwo Obuczenije, Moskwa 1979, s. 78-90; L.M. Wasiliew, Sowremennaja lingwisticzeskaja semantika, Izdatel'stwo Wysszaja szkoła, Moskwa 1990.

${ }^{26}$ W.M. Gorochow, Zakonomiernosti żurnalisticzeskogo tworczestwa, Izdatel'stwo Mys'l', Moskwa 1975; J.P. Prochorow, Wwedienije w teoriju żurnalistiki, Izdatel'stwo Aspiekt Press, Moskwa 1973; G.W. Lazutyna, Osnowy tworczeskoj diejatel'nosti żurnalista, Izdatel'stwo Aspiekt Press, Moskwa 2000.

${ }^{27}$ E.W. Czepkina, Russkij żurnalistskij dyskurs. Tekstoporozhdajuszczije praktiki $i$ kody (1995-2000), Izdatel'stwo Ural'skogo uniwiersitieta, Jekaterynburg 2000.

${ }^{28}$ A.A. Tertycznyj, Żanry priessy, Izdatel'stwo Aspiekt Press, Moskwa 2000. 
sposób dziennikarz kształtuje poglądy i określa stopień ważności tego, o czym informowały środki masowego przekazu. Obiektami dziennikarskiego oceniania, jako podstawami kształtowania się tekstu, mogą być: 1) wydarzenie, 2) osoba, 3) cudzy komunikat, 4) stan rzeczy, 5) cudza opinia, 6) dzieło sztuki. W publikacji Tatiany B. Troszewej opisana jest typologia rozmyślania, która włącza takie formy rozmyślania, jak: wytłumaczenie, uzasadnienie, potwierdzenie, sprostowanie ${ }^{29}$. W publikacjach oceniających wydarzenia i osoby dziennikarz tłumaczy swoją aprobatę lub pochwałę, potępienie lub szyderstwo. Jeśli zaś dziennikarz kwestionuje jedne komunikaty, pochodzące od innych autorów, to podczas polemiki opiera się na innych komunikatach i potwierdza je. Swoją wypowiedzią o sytuacji problemowej dziennikarz uprzedza natomiast słuchaczy o możliwym zagrożeniu i uzasadnia swój negatywny stosunek wobec sytuacji. Wychwalając wybitnych ludzi albo demaskując wady innych, także uzasadnia swoją ocenę. Oceniając cudzą opinię, zgadza się z jednymi sądami, a innym się sprzeciwia, nieraz potwierdzając słuszność swojego punktu widzenia. Uznanie wydarzeń i zjawisk za dzieła sztuki albo wyrażenie krytycznego stosunku wobec nich wymaga potwierdzenia. Wśród oceniających gatunków mowy wyróżniają się pozytywnie oceniające - aprobaty, pochwały, laudacje, zgody i uznania, oraz negatywnie oceniające - potępienia, krytyki, szyderstwa, demaskacje, zaprzeczenia i uprzedzenia, które konstytuują się we współdziałaniu z czytelnikiem na podstawie różnych form rozmyślania tłumaczenia, uzasadnienia, sprostowania i potwierdzenia.

Trzecia grupa gatunków - motywujących - jest reprezentowana przez kilka gatunków mowy w zależności od tego, do jakich działan autor zamierza zachęcić, jaką aktywność chce wywołać: wezwanie do działań, wymaganie działań, propozycja działań, zalecenie modelu działań, rekomendacja korekty, zachęcenie do wyboru wariantów rozwiązania problemu społecznego, instrukcje, przepisy i rady ${ }^{30}$.

\section{Dziennikarskie gatunki mowy jako typowe algorytmy realizacji zadań zawodowych}

Za gatunek mowy uważamy charakterystyczną dla dziennikarskiej działalności werbalnej utrwaloną tekstowo, kompozycyjno-stylistyczną formę reakcji mownej na tradycyjne w odniesieniu do mediów informacyjne oczekiwania ludzi; w tej formie skuteczność komunikacji jest gwarantowana przez typowy sposób koordynacji stanowiska autora wyrażonego treściowo i hipotez zakładanych przez odbiorcę. W oparciu o tekstowe rozumienie gatunku mowy warto przedsta-

\footnotetext{
${ }^{29}$ T.B. Troszewa, Otrażenije, [w:] Stilisticzeskij enciklopediczeskij stovar', s. 321-328.

${ }^{30}$ L.R. Duskajewa, Intencjonalnost'..., s. 253-260; taż, Stilisticzeskij intent-analiz..., s. 81-91.
} 
wić działalność mowną dziennikarza w wypowiedziach, które realizują zadania komunikacji zawodowej.

Psycholingwiści podkreślają, że zdania-wypowiedzi łączą się w tekst dzięki idei autora. To znaczy, że idea występuje jako podstawa wytwarzania mowy. Ale idea nie rodzi się od razu absolutnie skończona, stopniowo modyfikuje się pod wpływem zewnętrznych, nielingwistycznych okoliczności komunikacji, które w zawodowej działalności mownej związane są przede wszystkim z wykonywaniem obowiązków zawodowych. Wskazane jest, aby rodzajową typologizację utworów jako efektów zawodowej działalności mownej przeprowadzać na podstawie celów typowych, umotywowanych z zawodowego punktu widzenia. Te cele stanowią podstawę ukształtowania autorskiej idei, która realizując się następnie w tekście, staje się fundamentem dla powstania utworu.

Autorską ideę można wyobrazić sobie jako całokształt intencji (intencjonalność), urzeczywistniony w kompozycji tekstu w postaci skomplikowanego systemu komunikatów, działań komunikacyjnych, wśród których jedne są główne, ,inne dodatkowe, trzecie uzupełniające wobec drugich itd." ${ }^{31}$. Idea autorska determinuje kompozycję tekstu, w której odzwierciedla się „,budowa, korelacja, wzajemne rozmieszczenie części” utworu, „podział na elementy znaczeniowe, stopień i sposób wyrażenia tych elementów, porządek ich następowania i wzajemny związek"32. Tak więc kompozycja tekstu kształtuje się w efekcie jej wyłaniania się z głównej koncepcji, jaką początkowo jest idea, i szeregu koncepcji dodatkowych. Zgodnie z ideą zachodzi uporządkowanie formy tekstu, ustanawianie integralności struktury kompozycyjnej i zwartości tekstu.

Typowa autorska intencja, leżąca u podstaw tworzenia gatunku mowy, jest częścią struktury rozpatrywanej działalności zawodowej. Gatunek mowy w moim ujęciu stanowi typologiczną formę realizacji celu umotywowanego z zawodowego punktu widzenia, dlatego kompozycja gatunku stanowi urzeczywistnienie kolejności działań (subgatunkowych i elementarnych), odtwarzających obiektywną logikę osiągnięcia celów zawodowych. Kolejność tych werbalnych działań odtwarza sposób osiągnięcia takiego lub innego gatunkowego celu. Tak więc, w tekście medialnym, jak w każdym innym, odzwierciedla się nie tylko wynik, ale również proces wpływania działalności mownej subiekta na osiągnięcie celów zawodowych. Takie podejście pokazuje, jak w kompozycji tekstów medialnych wyrażają się mechanizmy oddziaływania informacyjnego, i jak w jednostkach mowy (działaniach, aktach, subgatunkach) rozwija się specyficzna działalność mowna. Lingwistyczna organizacja gatunku mowy warunkowana jest przez dynamikę jego struktury treściowo-semantycznej.

${ }^{31}$ T.M. Drydze, Tekstowaja dejatel'nost' w strukturie socjal'noj kommunikacii, Izdatel'stwo Obuczenije, Moskwa 1984.

${ }^{32}$ E.A. Bazhenowa, Kompozycija teksta, [w:] Stilisticzeskij enciklopediczeskij stovar', s. 168. 
Ze względu na takie podejście badacz w naturalny sposób skupia uwagę na złożonych, właściwych jednostkach mowy - działaniach mownych, które wyrażają się w celowym doborze środków językowych. W efekcie cały tekst, jako jednostka komunikacji (!), przejawia się w jego składnikach - jednostkach tekstowych: komunikacyjnych krokach, aktach mowy, gatunkach mowy, działaniach werbalnych odzwierciedlających kolejność, algorytmach zawodowych działalności mownej. Należy podkreślić, że językoznawca nie może ignorować okoliczności, że składniki powstają we współdziałaniu środków językowych, które stanowią o systemowości mowy. Jako przykład przedstawiam jeden z typowych algorytmów działalności mownej dziennikarza.

\section{Prezentacja gatunku „,rekomendacja korekty błędów"33}

Analiza materiału w niniejszej pracy pokazała, że wśród dziennikarskich publikacji analitycznych uformował się model gatunku, którego celem jest zalecenie korekty błędnego schematu działania prowadzącego do konfliktu. Ten model realizuje się w następujących interakcjach mownych: 1) uświadomienie istnienia konfliktu między uczestnikami interakcji; 2) wyjaśnienie czytelnikowi przyczyn konfliktu i wskazanie jego sprawców; 3) zmotywowanie do zlikwidowania konfliktu, skierowane do kompetentnych organów władz lub osób. Przejdźmy do analizy tekstów. Jako przykład posłuży publikacja prasowa Wody zapomnienia („Literaturnaja Gazeta” [„Gazeta Literacka”], 5-11.02.2003).

Pierwsza interakcja ukierunkowana jest na naświetlenie konfliktu, dlatego prezentuje się w niej starcie dwóch stron. Wyrażona ocena służy przekonaniu czytelnika o tym, że niewłaściwe działania, które doprowadzają do konfliktu, są nielegalne, sprzeczne z prawem i w zasadzie nieprawidłowe. Potrzeba podjęcia działań jest motywowana przez ocenianie.

W publikacji wskazano czas i miejsce konfliktu, jednak został on odniesiony do sfery subiektywności; jego podstawą jest sprzeczność między stosunkiem do cudownego miasteczka, na jaki zdaniem publicysty ono zasługuje, i barbarzyńskim traktowaniem go przez władzę. Stąd wzmocniona subiektywność w przedstawieniu stanu konfliktu:

Niedawno w Swijażsku po raz kolejny wyłączono prąd. Zresztą mieszkańcy Swijażska już od dawna do tego przywykli. Bowiem historia i Swijażskowi zgotowała dramatyczny los. Od wszechrosyjskiej sławy do absolutnego zapomnienia... Najlep-

${ }^{33}$ Należy przyjąć, że polskim odpowiednikiem tego gatunku byłby komentarz mający na celu interwencję w jakiejś sprawie [przyp. red.]. 
si budowniczowie Rosji wznosili wspaniałą architekturę. Dwanaście cerkwi wyrosło w Swijażsku, dwa klasztory. Wyobraźcie sobie piękno wznoszące się nad wodami i ląkami! Jakie zdumienie i zachwyt! Pierwsze blizny na obliczu miasta - to, oczywiście, rok 1918, kiedy szalała wojna domowa... Ale to było tylko preludium nieszczęścia. Prawdziwe nieszczęście nadeszło później... Cerkwie i klasztory zostały zbezczeszczone. W monasterze Zaśnięcia Matki Bożej ulokowano więzienie przejściowe... Ateiści niszczyli i wysadzali świątynie... Na początku lat pięćdziesiątych nadeszła druga fala zniszczenia. A ja byłem zmuszony stać się świadkiem nowego zbezczeszczenia najdroższego miejsca.

Jak widzimy, szczególne znaczenie w prezentowaniu konfliktu ma charakterystyka miejsca, w którym się on rozgrywa. Jest ono nie tylko wskazane, lecz emocjonalnie i barwnie opisane, dzięki czemu stan konfliktu jest obrazowany ze skrajnym napięciem.

Publicysta ukazuje barbarzyński stosunek wobec miasta. Osiąga się to za pomocą, z jednej strony, pozytywnie wartościującej wyszukanej leksyki: oblicze, budowniczowie, aby opisać miasteczko, z drugiej strony, leksyki o znaczeniu ,zadawać cierpienie" - metafor blizny na obliczu, druga fala zniszczenia, związku frazeologicznego nieszczesście nadeszło, imiesłowu biernego zbezczeszczone, rzeczowników odczasownikowych zniszczenie, zbezczeszczenie; czasowników niszczyli i wysadzali. W rezultacie takiego naświetlenia konfliktu czytelnik zostaje zaangażowany w proces nie tylko współmyślenia, ale też współprzeżywania.

Druga interakcja jest ukierunkowana na ujawnienie przyczyn konfliktu i jego uczestników. W tekście związek przyczynowo-skutkowy ustala się poprzez przedstawienie kolejności działań, które doprowadziły do wygaśnięcia życia w miasteczku:

Wówczas w Żygulach nad Wołgą wznosiła się hydroelektrownia... Kazań pospiesznie odgradzał się zaporami. I to oznaczało jedno: koniec! W końcu Swijażsk znikł jako jednostka administracyjna... Wszak cudowne miasteczko można było uratować! Trzeba było do tego tylko dobrej woli władzy... i drogi...

Barbarzyńskiemu stosunkowi do skansenu jest przeciwstawiona (spójnik przeciwstawny wszak, konstrukcja modalna można uratować) wizja autora, pełna zarówno desperacji, jak i nadziei. Nadziei na to, że uda się ożywić zainteresowanie ludzi tym cudownym miasteczkiem. I wówczas zostanie ono uratowane, ono musi być uratowane. Podobne uczucia przenikają zarówno uporczywe wołanie o ratunek miasteczka, jak i życzenie , dobrej woli władzy... i drogi...”.

Określając przyczyny konfliktu i ujawniając sprawcę stworzonej sytuacji, wyjaśnia się kierunek działań niezbędnych dla ,przywrócenia odpowiedniego porządku, zniszczonej harmonii”, a dziennikarz przekonuje czytelnika o potrzebie 
przedsięwzięcia środków, aby usunąć przyczyny konfliktu. Poświęcona jest temu trzecia interakcja. Zalecenia przedstawione $\mathrm{w}$ tym fragmencie są skierowane do konkretnych organizacji albo osób, winnych temu, co się stało. Dzięki wcześniejszym interakcjom czytelnik już jest przygotowany, żeby przyjąć sugestie wypowiedziane w zakończeniu przez publicystę. Czytelnicy już rozpoznali problem, wyrobiwszy sobie opinię o miasteczku umierającym, ale zdolnym do przyciągnięcia uwagi ludzi swoim zadziwiającym pięknem, bogatą historyczną przeszłością i wysoką wartością kulturalną. Później czytelnicy dowiedzieli się o tym, jak barbarzyństwo i wandalizm, właściwe polityce państwa radzieckiego, odbiły się na obliczu i losie miasta, tak więc motywacja do zmiany stosunku do miasta, skierowana do rządzących, trafi już na podatny grunt: „Odrodzenie Swijażska jako centrum turystycznego, jako muzeum-skansenu jest niezbędne. Jeśli, oczywiście, traktować to miasteczko po gospodarsku. Oszczędnie”. Sposób usunięcia konfliktu między stosunkiem władzy do miasta i tym, jaką wartość przedstawia to miasto, jest wyrażony w połączeniu bezokolicznika ${ }^{34}$ i spójnika jak. Odpowiedź na pytanie, jak działać, zawarta w wypowiedzeniu składowym w zdaniu podrzędnym okolicznikowym, jest wyrażona z pomocą połączenia bezokolicznika traktować razem z przysłówkami oszczędnie, po gospodarsku. Przysłówki te ze względu na ich wartościowanie sprzyjają uzasadnieniu słuszności wypowiedzianego zalecenia.

Analiza tekstów prasowych pokazuje, że w stylu dziennikarskim istnieje klasa tekstów, których kompozycję można przedstawić jako zestaw trzech interakcji: oceniającej (służącej ocenie relacji konfliktowej); interakcji pytanie-odpowiedź (ukierunkowanej na szukanie albo wytłumaczenie czytelnikowi przyczyn konfliktu i określenie jego sprawców); motywującej (proponującej sposób usunięcia konfliktu). Każda interakcja wyraża się w swoim oryginalnym zestawie środków językowych, kształtujących systemowość mowy we wzajemnym oddziaływaniu.

\section{Wnioski}

W artykule ogólnie przedstawiono algorytm analizy dziennikarskiego stylu zawodowego, który przede wszystkim tworzy trójczłonowy system gatunków mowy. Wyróżnia się je na podstawie twórczych intencji współdziałania dziennikarza $\mathrm{i}$ adresata, które kształtują się $\mathrm{w}$ procesie społecznej orientacji realizowanej w dziennikarstwie ${ }^{35}$. Wyróżnione intencje nie występują samodzielnie, lecz współ-

\footnotetext{
${ }^{34} \mathrm{~W}$ tłumaczeniu jest to wyrażone $\mathrm{w}$ formie rzeczownika odczasownikowego i bezokolicznika [przyp. tłum.].

${ }^{35}$ L.R. Duskajewa, Intencjonalnost'..., dz. cyt.
} 
działają ze sobą i tworzą system, w którym realizuje się ukierunkowanie społeczne dziennikarstwa. Każdy wyróżniony gatunek mowy jest stabilną sekwencją (algorytmem) werbalnych interakcji, realizacja których prowadzi do wykonania tego czy innego, typowego zawodowego zadania. Oprócz cech stylu wspólnych dla makrostylu publicystycznego ${ }^{36}$, istnieją także cechy specyficzne, które w każdym gatunku mowy wyrażają się oryginalnie - za pomocą logiki faktów, oceny społecznej, mobilizacji decydentów. Analiza stylistyczna mowy nawet jednego modelu gatunku - motywującego - pokazuje, że w ten sposób można analizować typowe algorytmy realizowania zawodowo mownej działalności dziennikarza. Badanie dowodzi, że ogólnie rzec biorąc, zaproponowana analiza stylistyczna zawodowych odmian działalności mownej może być produktywna dla badania „gramatyki językowej w akcji” ${ }^{37}$ - w aktywnie rozwijającym się dziennikarskim obszarze komunikowania.

\section{Bibliografia}

Aructunowa N.D., Jazyk i mir czełowieka, „Slawianskij Jazyk i Kul’tura” 1999.

Bazhenowa E.A., Kompozycija teksta, [w:] Stilisticzeskij enciklopediczeskij słovar', ried. M.N. Kożyna, Izdatiel'stwo Flinta, Moskwa 2003, s. 168.

Bryzgunowa J.P., Semanticzeskaja sowmestimost' teksta. Sintaksis teksta, Izdatel'stwo Obuczenije, Moskwa 1979, s. 78-90.

Chehova M., Chloupek J., Krčmova M., Minařova E., Současna česka stylistika, ISV, Praha 2003.

Corbett B.J., Genre and genre analysis, Encyclopedia of Language and Linguistics, ed. E.K. Brown, A. Anderson, Elsevier, Boston 2006.

Czepkina E.W., Russkij żurnalistskij dyskurs. Tekstoporozhdajuszczije praktiki i kody (1995-2000), Izdatel'stwo Ural'skogo uniwiersitieta, Jekaterynburg 2000.

Dementjew W.W., Teorija reczewych żanrow, Izdatel'stwo Znak, Moskwa 2010.

Drydze T.M., Tekstowaja dejatel'nost' w strukturie socjal'noj kommunikacii, Izdatel'stwo Obuczenije, Moskwa 1984.

Duskajewa L.R., Dialogiczeskaja priroda gazetnych reczewych żanrow, Izdatel'stvo Permskogo universiteta, Perm 2004; 2 soz.: Izdatel'stwo Sankt-Peterburgskogo uniwersiteta, Sankt Petersburg 2012.

Duskajewa L.R., Intencjonal 'nost' reczewoj dejatel'nosti żurnalista. Ontologija i struktura, „Vestnik Sankt-Peterburgskogo Universiteta” 2012, Serija 9: Filologija, Wostokowedenije, Żurnalistika, nr 2, s. 253-260.

Duskajewa L.R., Stilisticzeskij intent-analiz kak wektor izuczenija reczewych raznowidnostej, „Medialingwistika” 2013, t. 1, s. 81-91.

Formanowska N.I., Reczewoje obszczenije. Kommunikatiwno-pragmaticzeskij podhod, Izdatel'stwo Russkij jazyk, Moskwa 2002.

Gajda S., Probliemy żanra, [w:] Funkcjonalnaja stilistika. Teorija stilej i ich jazykowaja realizacija, Izdatiel'stwo Permskogo uniwiersiteta, Perm 1986.

\footnotetext{
${ }^{36}$ M.N. Kożyna, L.R. Duskajewa, W.A. Salimowski, dz. cyt.

37 Definicja T. Kotarbińskiego.
} 
Gajda S., Stilistika i genealogija. Status stilistiki w sowremennom jazykoznanii, Izdatiel'stwo Permskogo uniwiersiteta, Perm 1992.

Gauzenblas K., K utoczneniju ponjatija , stil” $i$ k voprosu ob objome stilisticzeskogo issledowani$j a$, „Woprosy Jezykoznania” [„Problemy Językoznawstwa”] 1965, nr 5.

Gauzenblas K., Suszczestwujet li „,neytralnyj stil”?, [w:] Funkcjonalnaja stilistika. Teorija stilej i ich jazykowaja realizacija, Izdatiel'stwo Permskogo uniwiersiteta, Perm 1986.

Gorochow W.M., Zakonomiernosti żurnalisticzeskogo tworczestwa, Izdatel'stwo Mys'l', Moskwa 1975.

Grabias S., Język w zachowaniach społecznych, wyd. 2 popr., Wydawnictwo UMCS, Lublin 1997.

Kara-Murza J.S., Kul'tura reczi w reklamnoj dejatel'nosti, „Żurnalistika i Kul'tura Reczi” 1996, wyp. 1.

Kostomarow W.G., Russkij jazyk w żurnalie, Izdatiel'stwo Moskowskogo uniwiersiteta, Moskwa1971.

Kożyna M.N., Duskajewa L.R., Salimowski W.A., Stilistika russkogo jazyka, Izdatiel'stwo Flinta, Moskwa 2008.

Kożyna M.N., Stilistika russkogo jazyka, Izdatiel'stwo Proswiesienie, Moskwa 1977.

Kożyna M.N., Systemowost' reczi, [w:] Stilisticzeskij enciklopediczeskij słovar', red. M.N. Kożyna, Izdatiel'stwo Flinta, Moskwa 2003, s. 347-350.

Lazutyna G.W., Osnowy tworczeskoj diejatel'nosti żurnalista, Izdatel'stwo Aspiekt Press, Moskwa 2000.

Mistrik J., Štylistika, Wydawnictwo SPN, Bratislava 1997.

Moessnar L., Genre, text type, style, register. A terminological maze, "European Journal of English Studies" 2001, No. 5 (2), pp. 131-138.

Prochorow J.P., Wwedienije w teoriju żurnalistiki, Izdatel'stwo Aspiekt Press, Moskwa 1973.

Przewodnik po stylistyce polskiej, red. nauk. S. Gajda, Uniwersytet Opolski, Opole 1995.

Salimowski W.A., Żanry reczi $v$ funkcjonalno-stilisticzeskom oswieszczenii (nauczny akademicki tekst), Izdatiel'stwo Permskogo uniwiersiteta, Perm 2002.

Solganik G.J., Stil' reportaża, Izdatiel'stwo Moskowskogo uniwiersiteta, Moskwa 1970.

Szmielowa T.W., Reczewoj żanr, „Rusistika” 1990, wyp. 2.

Tertycznyj A.A., Żanry priessy, Izdatel'stwo Aspiekt Press, Moskwa 2000.

Troszewa T.B., Otrażenije, [w:] Stilisticzeskij enciklopediczeskij słovar', ried. M.N. Kożyna, Izdatel'stwo Flinta, Moskwa 2003, s. 321-328.

Wasiliew L.M., Sowremennaja lingwisticzeskaja semantika, Izdatel'stwo Wysszaja szkoła, Moskwa 1990.

Wasiljewa A.N., Gezetnogo-publiczistyczeskij stil, Izdatiel'stwo Russkij jazyk, Moskwa 1982.

Wierzbicka A., Uniwersal'nyje semanticzeskije primitiwy kak klucz k leksiczeskoj semantike (sfiera emocij), „Reczewyje Żanry” 2005, wyp. 4, s. 158-182.

Wojtak M., Gatunki prasowe, Wydawnictwo UMCS, Lublin 2004. 
Lilia R. Duskajewa

\section{Professional journalistic style. An attempt to define}

\section{(Summary)}

The article substantiates the distinction of professional journalistic language as a variant of langue representing journalistic style, and implemented in three groups of speech genres - informing, estimating and stimulating. Alongside stylistic features common with journalistic macrostyle, this professional language has its own specific characteristics, expressed through faithfulness to the facts, social estimation and administrative stimulation. Stylistic analysis of even only one genre - stimulating - reveals that the professional and linguistic activities of journalists can be analysed as typical execution algorithms, using the aforementioned method. The article demonstrates that the proposed analysis of speech representations in professional language can be productive for the study of language in action in the journalistic sphere of communication.

Keywords: professional language, speech genres, social problem. 